\title{
Functionomics: the analysis of a postgenomic concept on the basis of pregenomic pharmacological studies in smooth muscle
}

\author{
ARON JURKIEWICZ, AFONSO CARICATI-NETO and NEIDE H. JURKIEWICZ \\ Departamento de Farmacologia, Universidade Federal de São Paulo, Rua 3 de Maio, 100, 04044-020 São Paulo, SP, Brasil \\ Manuscript received on July 8, 2008; accepted for publication on May 25, 2009 \\ contributed by ARON JURKIEWICZ*
}

\begin{abstract}
The term functionomics (Amin 2003, Neumann et al. 2004) refers to a postgenomic integrated Systems Biology (Attur et al. 2002) using a multidimensional approach for cells, tissues and organs. It considers current or future involvement among genomics, proteomics or metabolomics, including the main factors that cause biological responses and modulation under different conditions. Our objective in the present review is to summarize the contemporary understanding of functionomics of smooth muscle pharmacology, based on the results obtained on the pregenomic era during several years in our laboratory. The present approach is based on the knowledge of the dynamics of the receptor system, which comprises a cascade of phenomena, leading from the drug administration to the final biological response. We will describe several conditions in which the final effect is modified, based on perturbations induced on drug absorption, distribution, metabolism, interaction with receptors and mobilization of second messengers, as well as by interactions with a second receptor system. We will also discuss the gaps that need to be fulfilled in order to obtain a clear and better understanding of the receptor system in smooth muscle, and to narrow the bridge between our knowledge of the function of biological systems, genomics, and other recently introduced areas.
\end{abstract}

Key words: functionomics, receptor, smooth muscle, genomic.

\section{INTRODUCTION}

Less than 10 years ago, the outstanding journal Science published a number of reviews under the title "Wholeistic Biology" (Chong and Ray 2002). This period is being named as the postgenomic era (Amin 2003), when a field named as Systems Biology was considered (Attur et al. 2002), in which genes and other agents are taken into account. The main goal was to verify how changes to one part of a system may affect other parts (Kitano 2002, Davidson et al. 2002). With the rapid progress of genomics, the emphasis has initially given rise to the science of proteomics and metabolomics, namely the study

In commemoration of the $75^{\text {th }}$ anniversary of Escola Paulista de Medicina / Universidade Federal de São Paulo.

* Member Academia Brasileira de Ciências

Correspondence to: Dr. Aron Jurkiewicz

E-mail: aron.farm@epm.br of all the proteins and its metabolism produced by cells and organism, involving the identification of proteins and biotransformations in the body. This was followed by functionomics (Amin 2003, Neumann et al. 2004) with attempts to fetch the corresponding functions.

A major challenge to be foreseen in functionomics is the integration of proteomics with genomics and metabolomics data, and mainly the integration with their physiological and pathophysiological functional interpretation, in conjunction with clinical results and epidemiology. To explore such a vast space, new forms to exploit and link these fields with pharmacological data will be essential to ask possibly new kinds of questions about the complex nature of therapeutics. This integration is meant to follow different routes, either from the gene to the function, or vice-versa. 
A number of technical obstacles remain before functionomics can have strengthened its interpretation in conjunction with routine genomics, proteomics and metabolomics: (a) more than $40 \%$ of the 35,000 genes (and possibly 120,000 different proteins they may code) have not been ascribed any functional attribute, neither a biochemical or cellular function nor a function at the tissue/organism level (Attur et al. 2002); (b) on the other hand, there is a large number of functions that still remain to be correlated with genes and proteins (Amin 2003); (c) when dealing with a gene-driven approach and a phenotype-driven approach, it has to be considered that in general the genetic information is static, while the functional correlate is dynamic (Davidson et al. 2002).

One of the methods used to check for correlations between the different parts of the receptor system cascade (Fig. 1) is to introduce a perturbation in the biological system and to track the steps which lead to the changes observed on the final response. In our lab, various alterations have been detected in vas deferens after different types of spontaneous or induced perturbations, such as denervation, castration, transplantation, hypothermia, aging, genetic hypertension, neurodegenerative diseases, or the involvement of a second receptor system. These points will be summarized below, in the light of the alleged receptor system cascade, as functional candidates for the $40 \%$ of gene population whose function is still unknown.

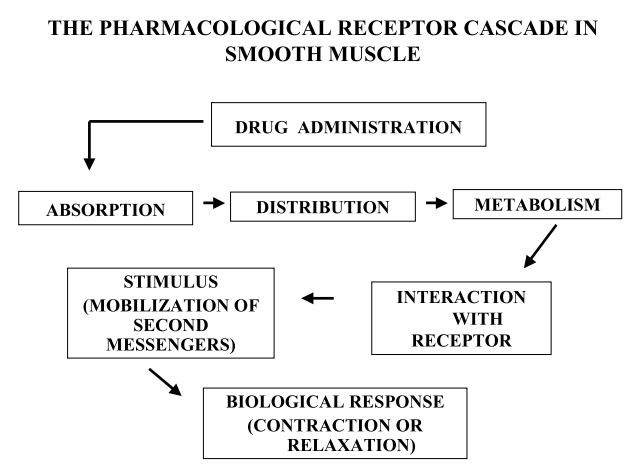

Fig. 1 - The receptor system cascade in smooth muscle, modified from Ariens (1954).

\section{THE RECEPTOR SYSTEMS IN SMOOTH MUSCLE}

The initial functional studies on drug-receptor interaction were mainly due to the pioneering publications of Hill (1909) and Clark (1926, 1933), when the molecular structure of receptors was still unknown. The structures were still a matter of speculation when Ariens (1954, 1964) presented a Receptor Theory, based mainly on the study of pharmacological receptors in muscle. The receptor was depicted as part of a chain of events which included phenomena preceding the interaction of drugs with receptors (absorption, distribution, metabolism) as well as following the formation of the drug-receptor complex (stimulus) leading to the biological response. The ability to form the stimulus was independently named as intrinsic activity by Ariens (1954), or efficacy by Stephenson (1956). Shortly after, attention was given to the so-called intrinsic efficacy and to the biophase, an organ compartment where receptors are supposed to be located (Furchgott 1964, Furchgott and Bursztyn 1967, Furchgott et al. 1973). Furthermore, a new parameter, relative responsiveness, was presented to compare receptor systems with each other (Jurkiewicz et al. 1969, 1976).

In the last decades of the previous century, the Ariens' so-called stimulus was already considered as a transducing or signaling pathway, comprising second messengers such as cyclic AMP (Sutherland 1972), Gproteins (Hill 2006, Milligan and Kostenis 2006), and some ions as calcium (Jurkiewicz et al. 1975, 1994b, Castillo et al. 1992, Smaili et al. 1998, Verde et al. 2002, Lopes et al. 2006, 2007, Lafayette et al. 2008), sodium (Belevych et al. 1999), or potassium (Harhun et al. 2003). This picture was further improved thanks to the development of new methods, such as receptor binding with radioligands as for instance by Castillo et al. (1992), and electrical identification of selective ion channels (Belevych et al. 1999, Harhun et al. 2003). At this point the receptor could still be depicted as a cascade of phenomena, as suggested by Ariens, except that the stimulus was replaced by the mobilization of second messengers, as shown in Figure 1. An additional stimulating improvement was achieved thanks to the development of genomics, leading to the identification of genes expressing mainly receptors (Alexander et al. 2008) and ion channels (Catterall et al. 2002). Information was also collected about the duplicated functions of receptors, namely in active or inactive states, as well as about receptor phosphorilation, desensitization and internalization (Hill 2006). 
Although a correlation has been shown between genes, receptors and contraction in smooth muscle preparations, as for instance by Jurkiewicz et al. (2006), a more comprehensive picture is still missing concerning the role of different steps on the receptor cascade, as well as a dynamic overview of the influence of modulation, considering that receptor systems are greatly influenced by endogenous or external factors and can constantly undergo changes.

In spite of the consensus among various investigators that a single genetic approach is not sufficient to give a comprehensive picture of the receptor cascade, a number of points remain less considered, and deserve a more accurate analysis in order to pervade all the necessary steps:

(a) the fact that the cascade for a given receptor is not static, but can be modulated by various means,

(b) the need for more information about the strategies for measuring changes on receptor functions,

(c) the presence of functions that are still looking for a gene correlation, and

(d) the presence of a large number of results that have not been compared in parallel and need to converge to a structural, dynamic and systemic level.

\section{MODULATION BY FACTORS INDUCING PERTURBATIONS ON THE RECEPTOR SYSTEM}

Not surprisingly, it is known that a pharmacological effect is triggered by a pharmacological receptor, which is initially expressed by a gene; it is less known though that receptor systems, as depicted in Figure 1, can be altered and followed by means of perturbation analysis (Davidson et al. 2002), in which the biological object is modified experimentally or naturally, causing a parallel alteration on the operation of several signaling processes. In other words, the cascade of phenomena leading to the final biological response can be modulated, resulting in various different final effects, although generated from the same gene. This article sketches at least two underlying points that have been considered in our experiments: (a) the agents or modulation factors inducing perturbations, and (b) the resulting changes or functional linkages of the final effect. These points will be summarized below.

\section{INNERVATION}

The smooth muscle cells are part of organs or tissues that in general are innervated by sympathetic or parasympathetic neurons. Some of our experiments were performed by removing the influence of nerve tissue, by means of organ denervation. We have shown that surgical denervation causes a striking 30 -fold increase of the contractile responses induced by sympatomimetic drugs on the rat vas deferens, because of the removal of neuronal uptake (Jurkiewicz et al. 1991, 1992). This experiment clearly shows how a phenomenon preceding the drug-receptor interaction can modify the receptorinduced function. It is noteworthy that this increase is similar to that induced by cocaine in non-denervated vas deferens (Jurkiewicz and Jurkiewicz 1976). A second remarkable change caused by denervation is the highly significant decrease of the density of plasmalemal L-type voltage-dependent calcium channels, as shown through radioligand binding studies (Jurkiewicz et al. 1994b). In addition, we have also shown that a downregulation occurs for various enzymes of sarcoplasmic reticulum, such as calcium-magnesium ATP-ases involved in cellular calcium homeostasis (Quintas et al. 2005). Similar decreases were observed for alfa 2 subunit of sodium-potassium ATPases (Quintas et al. 2000, 2002). We have also described that the density of rianodine receptor in sarcosplasmic reticulum is decreased by about $45 \%$ after denervation of the vas deferens.

Since calcium is one of the most important second messengers for muscle contraction, including the vas deferens (Jurkiewicz et al. 1975, 1994b), this decrease leads obligatorily to general functional changes of drug effects.

\section{HORMONES}

Some organs and tissues are known to be hormone-dependent. This is the case for the rat vas deferens, as shown by the pioneering work of Martins and Valle (1939) after castration of male rats and other animal species. We have shown that, besides the well-known morphological changes due to the decrease of circulating testosterone, several hormone-induced pharmacological modifications might be related to modifications of calcium translocation (Jurkiewicz et al. 1977b, Calixto 
et al. 1983, Aucelio et al. 1985), that can be unquestionably ascribed to the striking decrease, of about $90 \%$, of the density of cell membrane calcium channels (Castillo et al. 1992).

\section{EPITHELIUM}

Since the classical experiments of Furchgott showing the function of epithelium as a source of nitric oxide (Vladimirova et al. 1994), our interest has been directed to the performance of experiments with epithelium-free vas deferens (Jurkiewicz et al. 1994a, Caricati Neto et al. 1995). As a matter of fact, an unexpected and distinctive result was obtained by Okpalaugo et al. (2002), showing that just the effect of the alpha 2 agonist clonidine was significantly increased after surgical excision of the epithelium, while the effects of other adrenergic and cholinergic drugs were not changed. It is still unknown whether or not this effect is related to the influence of a still unidentified endogenous agent (Jurkiewicz and Jurkiewicz 1992), that might have been removed together with the epithelium.

\section{GenETIC FACTORS}

Hypertension is still one of the most unresolved therapeutic problems. It is a consequence of functional changes that involve not only the cardiovascular system, but also other tissues and organs, as could be observed for the vas deferens of the rat genetically modified SHR (Spontaneously Hypertensive Rat). We have shown that there is a significant increase of alpha-adrenoceptors in this organ (Caricati Neto et al. 1992), a condition which can be related to the increase of blood pressure due to the involvement of arterial smooth muscle. More recently, we have shown for the first time that catecholamine release has greater quantal content and faster kinetics in isolated chromaffin cells of SHR, measured through single vesicle amperometry (Miranda-Ferreira et al. 2008, 2009).

\section{AGING}

Due to increased human lifetime expectancy during the recent decades, aging has become an important pharmacological issue. We have shown recently that several drug functions are modified in smooth muscle of senescent rats. For instance, calcium intracellular stores in sar- coplasmic reticulum and mitochondria of rat colon are changed in aged rats, affecting gastrointestinal smooth muscle motility in response to cholinergic neurotransmitters (Lopes et al. 2006). Studies were also made with cholinergic agents in rat jejunum of aged rats, showing a relation of these changes to an aging-modified calcium translocation (Lopes et al. 2007).

It should be emphasized that the influence of age can also be shown when studying newborn animals (Csaba 1980). As a matter of fact, we have shown that rat pups injected with the calcium channel blocker nifedipine presented an up-regulation of these channels in rat vas deferens (Verde et al. 2002). In addition, in another experimental approach, a reversible decrease of responsiveness to serotonin and noradrenaline was detected for pups that were breast-fed with the milk of mothers injected daily with the serotonin neuronal uptake blocker fluoxetine (Pereira et al. 2007). Since these mothers were also injected during pregnancy, it is quite possible that this treatment also influenced the pups during fetal life.

\section{HYPOTHERMIA}

Low temperature is an important agent for organ preservation ex vivo, mainly when considered for acute transplantation. In some cases, the organs have to be maintained in special nutrient solutions under ischemic conditions during several hours before transplantation. We have shown that small bowel segments (usually jejunum) presented autonomic dysfunctions when maintained under these conditions. In general, there was a reduction of the cholinergic function after up to 24 hours of hypothermia, although some drugs as heparin, ascorbic acid, and allopurinol attenuated the functional changes (Taha et al. 2004a, b, 2006). This dysfunction might be due to a partial degeneration of nerve tissue, which is known to occur under hypothermia before the changes of muscle cells take place (Jurkiewicz et al. 1992).

\section{TRANSPLATATION}

Several pharmacological and morphologic alterations were observed when the vas deferens was transplanted to the anterior wall of the cecum. (Jurkiewicz et al. 1977a). Besides a rapid denervation followed by a slow re-innervation during the subsequent 30 days (Jur- 
kiewicz et al. 1991), we have clearly detected, in the initial days, a functional change in the balance between $\alpha_{1 \text { a }}$ and $\alpha_{1 \mathrm{~b}}$ adrenoceptor populations (Pupo and Jurkiewicz 1997). This can be considered as a clear functional demonstration of a change of two subtypes of $\alpha$-adrenoceptors through this procedure.

\section{Neurodegenerative diseases}

We have studied a model for Huntington disease by treating rats with 3-nitroproprionic acid, an inhibitor of complex II of respiratory chain. This was followed by measurements of apoptosis, calcium translocation and behavior. It was suggested that these three effects might be interrelated and may precede degenerative processes. In other words, we have shown through this model that these signaling agents were modified in a parallel fashion, suggesting that a similar neurological abnormality occurs in humans (Rosenstock et al. 2004).

\section{INVOLVEMENT OF UNEXPECTED RECEPTOR SITES}

In a study aimed to analyze the effect of a group of cholinesterase blockers used for the treatment of Alzheimer's disease, namely galantamine, tacrine, rivastigmine and donepezil, we have observed that, besides blocking the enzyme, these agents were also unexpectedly able to enhance the purinergic neurotransmission in rat vas deferens (Caricati Neto et al. 2004). It was also observed by Santos et al. (2002) that galantamine causes an allosteric modification of nicotinic receptors. It is still unknown whether or not these effects are involved in the treatment of this disease. In other unrelated experiments we have observed that the endogenous agent agmatine induces a contractile effect in the rat vas deferens whose receptor involved could not be clearly identified, in spite of the use of a number of receptor blockers (Jurkiewicz et al. 1996). In another further publication, we have reported for the first time that nitric oxide behaves as a second messenger for the neurotransmission in rat vas deferens (Vladimirova et al. 1994). Finally, in a recent study, we have verified that the androgenic hormone testosterone interacts with a non-genomic site whose nature is still unknown, inducing a fast relaxation of the rat vas deferens, contrary to the expectations for the well-known slow genomic morphologic alteration (Lafayete et al. 2008).

\section{PUTTING TOGHETHER GENOMICS AND FUNCTIONOMICS}

We have studied the contractile responses of the rat testicular capsule (RTC), which is a thin tissue surrounding the testis, whose precise function is still unknown (Jurkiewicz et al. 2006). Simultaneously, RT-PCR assays were also made. From the functional standpoint, the adrenergic receptor (AR) subtypes were characterized through neurogenic contractions elicited by electrical field stimulation (EFS), noradrenaline, or by the blockade by antagonists of AR. In addition, the RT-PCR assays were made to check for the expression of the three presently known subtypes of $\alpha_{1}$-ARs. The effects of EFS showed that the release of NA from sympathetic nerves, contrary to ATP, was involved in contractions. The $\alpha_{1}$-selective antagonist prazosin was more effective than the $\alpha_{2}$-selective antagonist idazoxan to inhibit EFS-contractions, pointing out a major involvement of $\alpha_{1}$-AR. The contractions by NA were competitively blocked by $\alpha_{1 \mathrm{~A}^{-}}$and $\alpha_{1 \mathrm{~B}^{-}}$, but not by $\alpha_{1 \mathrm{D}^{-}}$-selective AR antagonists. Interaction with $\alpha_{2}-\mathrm{AR}$ antagonists was negligible. Summarizing, the results on contraction show the presence of functional $\alpha_{1 \mathrm{~A}}$ - and $\alpha_{1 \mathrm{~B}}-\mathrm{ARs}$, but not of $\alpha_{2}-$ and $\alpha_{1 \mathrm{D}}-\mathrm{ARs}$ in rat testicular capsule. In relation to RT-PCR assays, the presence of mRNA encoding $\alpha_{1 \mathrm{~A}^{-}}$ and $\alpha_{1 \mathrm{~B}}-\mathrm{AR}$ was also shown. One of the main, though unexpected findings was that a $\alpha_{1 \mathrm{D}}$-transcript was also detected in these assays, contrary to the functional results. Taken together, our results show that contractions involve the interaction of NA with both $\alpha_{1 \mathrm{~A}^{-}}$and $\alpha_{1 \mathrm{~B}^{-}}$, but not with $\alpha_{1 \mathrm{D}^{-}}$or $\alpha_{2}$-AR subtypes. It is surprising that the $\alpha_{1 \mathrm{D}}$-AR subtype could not be detected by contraction experiments, in spite of its presence as the corresponding mRNA. It is suggested that the $\alpha_{1 \mathrm{D}}-\mathrm{AR}$ gene might be linked to another function that is unrelated to contraction.

\section{LOOKING FOR GAPS BETWEEN GENOMICS AND RECEPTOR FUNCTION}

One of the main goals in functionomics is to find out if and how changes of a final biological response occur in parallel with modifications of the corresponding genes. The key difficulty resides in the fact that a complex biological response, as for instance a contraction, or a release of a neurotransmitter, or a hormonal secretion, depends on a chain of events involving many 
genes. For instance, in the case of a drug-induced contraction, multiple genes can participate in steps such as drug metabolism, release and synthesis of second messengers, crossing of ions through selective channels, and others, as advanced in Figure 1. For instance, we have described above that a contractile drug effect is modified by organ denervation or transplantation due to blockade of neuronal uptake, or by animal castration due to changes of the density of calcium voltage-dependent channels, or by genetic factors, such as hypertension, due to modifications of the adrenoceptor proper. Another example is the change of final biological response when a down regulation occurs for ATPases of sarcoplasmic reticulum after denervation. Other changes were also described above for aging and hypotermia, which are still expecting for a clear correlation with the corresponding genes, as well.

Furthermore, although a large number of genes has been identified, the expected functional matching is still missing, as shown for the $\alpha_{1 \mathrm{D}}$-AR subtype in testicular capsule. This confirms the well-known fact that genes, whose nature or correlation with a function is still unknown, are present.

\section{CONCLUSIONS}

Our main objective was to use a phenotype-driven approach, which analyzes phenotypes from a dynamic point of view, based on changes on the function of receptors induced by naturally occurring variants (hypertension, aging, neurodegenerative diseases) or by surgical procedures (castration, denervation, transplantation, removal of epithelium), as a tool to identify and characterize genes for the phenotype without prior knowledge of the underlying molecular mechanism or function. One of the main and still unanswered questions is whether or not these changes occur simultaneously with modifications of the corresponding genes.

Some interesting challenges were described when functional and genomic data were analized toghether in our lab, on the grounds of functionomics, as described above. The most interesting result is the finding that both $\alpha_{1 \mathrm{~A}}$ - and $\alpha_{1 \mathrm{~B}}$ - adrenoceptors were detected through both types of approach, while the presence of mRNA for $\alpha_{1 \mathrm{D}}$-AR subtype was not shown by RT-PCR, in spite of the demonstration of this subtype on contraction ex- periments. This is an initial outcomming on functionomics clearly showing, as expected, that a given gene might have different independent functions in a very same preparation or system. A similar partial lack of correlation between function and genomics was also described for adrenoceptors in rat seminal vesicle (Silva et al. 1999). This approach also opens new possibilities for other studies attempting to verify how the elements of a given receptor cascade are related to one or more genes.

Genomic influence is clearly present in many of the sites of the receptor system cascade, especially with reference to recent data about the relationship between genes and receptors (Alexander et al. 2008), and ion channels (Catterall et al. 2002). However, these studies have not yet taken full advantage of the many functional quantitative results obtained in the last years in order to construct more elaborated general models for functionomics. Similarly, many of the functional results cannot yet be explained by applying the principles of molecular or cell biology, nor by looking for the corresponding genes. It is clear that the crucial integrated information resides neither in the genome databases alone, nor in the individual proteins coded by the genes, but depends on knowing the black box in which the extent of protein interactions with cells, tissues, organs and systems are also at hand. One has to agree that applications and the potential of functionomics are at the moment invigorating (Noble 2002). The present climate faces several challenges for those attempting to perform funtionomic research, namely to explore functionality in a quantitative manner all the way from the level of the gene to that of the cell, and to the physiopharmacologycal functions of whole organs plus modulation and regulatory systems, according to the expectations for the postgenomic era.

\section{RESUMO}

O termo funcionômica (Amin 2003, Neumann et al. 2004) refere-se a um estudo posgenômico de Biologia de Sistemas (Attur et al. 2002), usando um enfoque multidimensional, dinâmico e simultâneo para células, tecidos e órgãos. Considera o envolvimento presente e futuro da genômica, proteômica e metabolômica incluindo os principais fatores que causam a resposta biológica final e sua modulação em diferentes con- 
dições. Nosso objetivo na presente revisão é resumir o nosso conhecimento atual em relação à funcionômica da farmacologia da musculatura lisa, baseada em resultados que obtivemos ainda na era pregenômica, durante vários anos em nosso laboratório. O presente enfoque baseia-se no que sabemos hoje em dia sobre a dinâmica do sistema receptor, que compreende uma cascata de fenômenos, que vão desde a administração de uma droga até a resposta biológica. Descreveremos várias condições nas quais a resposta é modificada, com base em perturbações produzidas na absorção, distribuição e metabolismo de fármacos, interação com receptores, mobilização de segundos mensageiros, bem como interações com um segundo sistema receptor. Discutiremos também o papel da genômica e as inúmeras falhas que devem ser preenchidas, para que se chegue a um conhecimento integrado e cada vez melhor dos sistemas receptores na musculatura lisa e para encurtar a ponte entre as funções do sistema biológico, genômica e outras áreas recentemente introduzidas.

Palavras-chave: funcionômica, receptor, musculatura lisa, genômica.

\section{REFERENCES}

Alexander SPH, Mathie A And Peters JA. 2008. Guide to Receptors and Channels (GRAC), $3^{\text {rd }}$ ed., $\mathrm{Br}$ J Pharmacol 153(Suppl 2): S1-S209.

AMIN AR. 2003. A need for a "whole-istic functional genomics" approach in complex human diseases. Arthritis Res Ther 5: 76-79.

ARIENS EJ. 1954. Affinity and intrinsic activity in the theory of competitive inhibition. Arch Int Pharmacodyn 99: $32-49$.

ARIENS EJ. 1964. Molecular Pharmacology, New York: Academic Press.

Attur MG, Dave MN, Tsunoyama K, Akamatsu M, Kobori M, MiKi J, ABRAMSON SB, KATOH M AND AMIN AR. 2002. A "System Biology" Approach to Bioinformatics and Functional Genomics in Complex Human Diseases: Arthritis. Curr Issues Mol Biol 4: 129146.

Aucelio JG, Calixto JB and Jurkiewicz A. 1985. Evidence for multiple sources of calcium involved on the contractile effects of agonists in the dog uterus. Influence of ovarian sexual hormones. Gen Pharmacol 16: 241-245.

Belevych AE, Zima AV, Vladimirova ia, Hirata H, JURKIEWICZ A, JURKIEWICZ NH AND ShubA MF. 1999. TTX-sensitive $\mathrm{Na}^{+}$and nifedipine-sensitive $\mathrm{Ca}^{2+}$ channels in rat vas deferens smooth muscle cells. Biochim Biophys Acta 1419: 343-352.

Calixto JB, Aucelio JG And Jurkiewicz A. 1983. Influence of castration of the neonatal rat on the contractile effects of barium chloride and adrenaline in isolated vas deferens: The role of calcium. Biol Reproduction 29: 1057-1062.

Caricati Neto A, Sette M and Jurkiewicz A. 1992. Increased density of $\alpha$-adrenoceptors in vas deferens of spontaneously hypertensive rats (SHR), indicated by functional and receptor binding studies. Eur J Pharmacol 218: $51-58$

Caricati neto A, Pupo As, Wanderley aG, NuñesVERgara M, Jun KOH IH, JURKIEWICZ NH AND JURKIEWICZ A. 1995. Role of the epithelium in the release of contractile agents from the rar vas deferens by clonidine. Ann NY Acad Sci 763: 436-439.

Caricati Neto A, D'Angelo LCA, Reuter H, JuRkiewicz NH, GARCiA A AND JURKIEWICZ A. 2004. Enhancement of purinergic neurotransmission by galantamine and other acetylcholinesterase inhibitors in the rat vas deferens. Eur J Pharmacol 503: 191-201.

Castillo CJ, Lafayette SS, Caricati Neto A, Sette M, JuRKIEWICZ NH, Garcia AG and JURKIEWICZ A. 1992. Low dihydropyridine receptor density in vasa deferentia of castrated rats. Br J Pharmacol 105: 257258.

Catterall WA, Chandy KG and Gutman GA. 2002. The IUPHAR Compendium of voltage-gated ion channels Royston, UK: Nightingale Press.

Chong L And RaY LB. 2002. Whole-istic biology. Science 295: 1661

CLARK AJ. 1926. The reactions between acetylcholine and muscle cells. J Physiol Lond 61: 530-546.

Clark AJ. 1933. The mode of action of drugs on cells. London: Edward Arnold \& Co, Chapter VII, p. 133.

CsABA G. 1980. Phylogeny and ontogeny of hormone receptors: the selection theory of receptor formation and hormonal imprinting. Biol Ver 55: 47-63.

DAVIDSON EH ET AL. 2002. A genomic regulatory network for development. Science 295: 1669-1678.

FuRCHGOTT RF. 1964. Receptor mechanisms. Ann Rev Pharmacol 4: 21-50.

FURChGOTT RF AND BURSZTYN P. 1967. Comparison of dissociation constants and of relative efficacies of selected agonists acting on parasympathetic receptors. Ann NY Acad Sci 144: 882-899. 
FurChgotT RF, JURKIEWICZ A AND JURKIEWICZ NH. 1973. Antagonism of propranolol, to isoproterenol in guinea-pig traquea. Some cautionary findings. In: UsDIN E AND SNYDER S (Eds), Frontiers on catecholamine research. New York: Pergamon Press, p. 295-299.

Harhun Mi, JuRKiewicz A, JuRKIEWICZ NH, KrysThtAl DO, ShubA MF AND Vladimirova IA. 2003. Voltage-gated potassium currents in rat vas deferens smooth muscle cells. Eur J Physiol 446: 380-386.

HILL AV. 1909. The mode of action of nicotine and curare determined by the form of the contraction curve and the method of temperature coefficients. J Physiol Lond 39: 361-373.

HILL SJ. 2006. G-protein-coupled. receptors: past, present and future. Br J Pharmacol 147(Suppl 1): S27-S37.

JURKIEWICZ A AND JURKIEWICZ NH. 1976. Dual effect of alpha-adrenoceptor antagonists in rat isolated vas deferens. Br J Pharmacol 56: 169-172.

JuRKIEWICZ A, JURKIEWICZ NH, BARRos G AND VALLE JR. 1969. Relative responsiveness $(\rho)$ of pharmacological receptors systems in the rat vas deferens. Pharmacology 2: 89-99.

Jurkiewicz A, Markus RP AND PiCARelli ZP. 1975. Effect of full agonists following calcium deprivation in rat vas deferens. Eur J Pharmacol 31: 292-304.

Jurkiewicz A, ABdo AO, JurkiewiCZ NH, Guedes AO AND SOUCCAR C. 1976. Relative responsiveness $(\rho)$ : critical analysis of a new method in receptor differentiation. Gen Pharmacol 7: 93-101.

Jurkiewicz A, JURKIEWICZ NH, GOMES CB AND AuCÉLIO JG. 1977a. Pharmacodynamic analysis of the rat isolated vas deferens after transplantation to intestinal wall. J Pharm Exp Therap 203: 112-119.

Jurkiewicz A, LANGeloh A AND Guedes AO. 1977b. Time-response curves for barium and noradrenaline in vas deferens of castrated rat. Eur J Pharmacol 45: 145-151.

Jurkiewicz A, Nunez-VErgara M, Koh I, CARicAtiNeto A, Pupo AS, Wanderley AG and JurkieWICZ NH. 1994a. Passive and active roles of the epithelium of the rat vas deferens mucosa on the contractile activity of smooth muscle. An Acad Bras Cienc 66: 124.

Jurkiewicz A, Lafayette SS, Nunes SH, Martini LC, Garcez do CARMo L, WANDERley AG AND JURKIEWICZ NH. 1994b. Decreased density of binding sites for the $\mathrm{Ca}^{2+}$ channel antagonist [3H]isradipine after denervation of rat vas deferens. Eur J Pharmacol 256: 329-333.
JURKIEWICZ NH AND JURKIEWICZ A. 1992. Release of contractile agents from rat vas deferens by clonidine. Life Sci 49: 1643-1649.

JurkiewiCz NH, JuRkiewiCZ A AND GARCiA AG. 1991. Reinnervation of the transplanted vas deferens: differential recovery of various biochemical and pharmacological parameters. J Neural Transm 85: 83-94.

JuRkiewiCz NH, GARCIA AG AND JURKIEWICZ A. 1992. In vitro denervation of the rat vas deferens through hypothermic storage. Br J Pharmacol 107: 610-615.

Jurkiewicz NH, CARmo LG, Hirata H, SAntos WC AND JURKIEWICZ A. 1996. Some Functional Properties of Agmatine in rat vas deferens. Eur J Pharmacol 307: 299-304.

Jurkiewicz NH, CARicati Neto A, Verde LF, AvelLAR M, REUTER HR AND JURKIEWICZ A. 2006. Sympathetic neurotransmission in the rat testicular capsule: functional characterization and identification of mRNA encoding a1-adrenoceptor subtypes. Eur J Pharmacol 543: 141-151.

KitAno H. 2002. Systems biology: a brief overview. Science 295: 1662-1664.

Lafayette SS, Vladimirova I, Garcez-do-Carmo L, Monteforte PT, CARicati Neto A AND JurkieWICZ A. 2008. Evidence for the participation of calcium in non-genomic relaxations induced by androgenic steroids in rat vas deferens. Br J Pharmacol 11: 1-9.

LOPES GS, FERreira AT, OSHIRO MEM, VLADIMIRova I, JURKIEWICZ NH, JURKIEWICZ A AND SMAili SS. 2006. Aging-related changes of intracellular $\mathrm{Ca}^{2+}$ stores and contractile response of intestinal smooth muscle. Exper Gerontol 41: 55-62.

Lopes GS, SMaili SS, CARicati Neto A, Vladimirova I, JurkiewiCZ A AND JurkiewiCz NH. 2007. Aging Induced Decrease of Cholinergic Response and Calcium Sensitivity on Rat Jejunum Contractions. J Gerontol 62A: 264-270.

MARTINS T AND VALLE JR. 1939. Endocrine control of the motility of the male accessory genital organs. Endocrinology 25: 80-90.

Milligan G And Kostenis E. 2006. Heterotrimeric G proteins: a short history. Br J Pharmacol 171(S1): S46S55.

Miranda-Ferreira RM, DePASCUAL R, DEDiego AMG, Caricati Neto A, Gandia L, JuRkiewicz A AND GARCIA AG. 2008. Single-Vesicle Catecholamine Release has greater quantal content and faster Kinetics in 
chromaffin cells from hypertensive, as compared to normotensive rats. J Pharmacol Exper Therap 324: 1-9.

Miranda-FERREIRA RM, DEPASCUAL R, CARICATI Neto A, Gandia L, Jurkiewicz A and Garcia AG. 2009. Role of endoplasmic reticulum and mitochondria on quantal catecholamine release from chromaffin cells of control and hypertensive rats. J Pharmacol Exper Therap 329: 1-10.

Neumann E, Gay RE, Gay S and Müller-Ladner U. 2004. Functional genomics of fibroblasts. Curr Opin Rheumatol 16: 238-245.

NoBLE D. 2002. Modeling the heart-from genes to cells to the whole organ. Science 295: 1678-1682.

OKPalaugo EO, Garcez do CARMo L, JuRKIEWICZ NH AND JURKIEWICZ A. 2002. Contractile responses of the rat vas deferens after epithelium removal. Life Sciences 70: 2943-2951.

Pereira JD, Caricati Neto A, Jurkiewicz A And JURKIEWICZ NH. 2007. Decreased noradrenergic and serotonergic reactivity of vas deferens of newborn rats from mothers treated with the serotonin reuptake inhibitor fluoxetine during pregnancy and breast-feeding. Life Sci 81: 1501-1508.

Pupo AS AND JuRKIEWICZ A. 1997. Functional change of the balance between alphala and alphalb adrenoceptor populations after transplantation of the vas deferens to the intestine. An NY Acad Sci 812: 290-294.

Quintas Lem, Caricati Neto A, Lafayette SSL, JURKIEWICZ A AND Noel F. 2000. Down-regulation of $\mathrm{Na}^{+} / \mathrm{K}^{+}$-ATPase alpha2 isoform in denervated rat vas deferens. Biochem. Pharmacol 60: 741-747.

Quintas LEM, LAFAyette SS, CARicati Neto A, JURKIEWICZ A AND NOEL F. 2002. Role of noradrenaline on the expression of the $\mathrm{Na}^{+} / \mathrm{K}^{+}$-ATPase alpha2 isoform and the contractility of cultured rat vas deferens. Biochem Pharmacol 64: 1431-1437.

Quintas lem, Cunha VMN, Scaramello CBV, Silva Clm, Caricati Neto A, Jurkiewicz A, Laffayette SS and Noel FG. 2005. Adaptive expression pattern of different proteins involved in cellular calcium homeostasis in denervated rat vas deferens. Eur J Pharmacol 525: 54-59.

Rosenstock TR, CARVAlHo ACP, JURKIEWICZ A, FRUSSA FILHO R AND SMAILI SS. 2004. Mitochondria calcium, oxidative stress and apoptosis in a neurodegenerative disease model induced by 3-nitropropionic acid. J Neurochem 88: 1220-1228.
Santos MD, Alkondon M, Pereira EF, AracaVa Y, Eisenberg HM, Maelicke A and Albuquerque EX. 2002. The nicotinic allosteric potentiating ligand galantamine facilitates synaptic transmission in the mammalian central nervous system. Mol Pharmacol 61: 1222 1234 .

Silva MA, Megale A, Avellar MCW and Porto CS. 1999. Expression and pharmacological characterization of $\alpha_{1}$-adrenoceptors in rat seminal vesicle. Eur J Pharmacol 381: $141-149$.

SMaili SS, CAVAlCANTI PM, OShIRo MEM, FERreira AT AND JurkiEWICZ A. 1998. $\mathrm{Ca}^{2+}$ Release-Activated Channels In Rat Stomach Smooth Muscle Cells. Eur J Pharmacol 42: 119-122.

STEPHENSON RP. 1956. A modification of receptor theory. Br J Pharmacol 11: 379-393.

SUTHERLAND EW. 1972. Studies on the mechanism of hormone action. Science 177: 401-408.

Taha MO, Fraga MM, Fagundes DJ, Jurkiewicz A AND CARICATI Neto A. 2004a. Ascorbic acid prevents autonomic dysfunction in rat jejunum submitted to cold ischemic preservation for transplantation. Transpl Proc 36: 289-292.

Taha MO, Fraga MM, Fagundes DJ, Jurkiewicz A AND CARicati Neto A. 2004b. Effect of allopurinol on autonomic dysfunction in rat jejunal segments exposed to cold ischemic preservation for transplantation. Transpl Proc 36: 293-295.

TAha MO, Fraga MM, Guimarães FA, JurkiewiCZ A ANd CARicAti Neto A. 2006. Atenolol attenuates autonomic dysfunction of rat jejunum submitted to cold ischemic preservation. Transpl Proc 38: 1784-1788.

Verde LF, Lafayette SSL, Caricati Neto A, JurKIEWICZ NH AND JURKIEWICZ A. 2002. Up-regulation of $\mathrm{Ca}^{2+}$ channels in vas deferens after chronic treatment of newborn rats with nifedipine. Eur J Pharmacol 403: $13-18$.

Vladimirova I, JuRKiewicz NH and JuRkiewicz A. 1994. Evidence for participation of nitric oxide in excitatory neurotransmitter in rat vas deferens. Life Sciences 55: $1123-1128$. 